\title{
Research trends of scientific literacy in Indonesia: Where are we?
}

\author{
Fatchiyatun Ni'mah \\ Universitas Nahdlatul Ulama Sunan Giri. Jalan Jend. Ahmad Yani No.10, Jambean, Sukorejo, Kec. \\ Bojonegoro, Kabupaten Bojonegoro, Jawa Timur 62115 Indonesia. \\ * Coressponding Author. E-mail: fatchiyatunn@gmail.com \\ Received: 15 August 2018; Revised: 28 February 2019; Accepted: 12 March 2019
}

\begin{abstract}
Scientific literacy has become a trend of research in various international research journals. These research trends also influence research trends in Indonesia. The purpose of this study is to analyze research related to scientific literacy in Indonesia based on articles published in various national journals. The analysis was conducted in term of methodological approach used and the subjects studied. The analysis was conducted on 138 articles published in various national journals, whether they have been indexed by SCOPUS, DOAJ or other journal indexing agencies. The findings indicate that the application of learning to increase student's scientific literacy is new research trend in Indonesia and commonly conducted in science major (IPA) with Junior High School students as samples. This study provides an overview of perspectives in scientific literacy research in Indonesia.
\end{abstract}

Keywords: literacy research trends, scientific literacy

How to Cite: Ni'mah, F. (2019). Research trends of scientific literacy in Indonesia: Where are we?. Jurnal Inovasi Pendidikan IPA, 5(1), 23-30. doi:https://doi.org/10.21831/jipi.v5i1.20862

doi https://doi.org/10.21831/jipi.v5i1.20862

\section{INTRODUCTION}

Literacy has been familiar for us recently. The word literacy became the center of attention after various surveys, conducted by PISA and TIMSS, stated Indonesian students were low ranked (Ni'mah, 2016). This is certainly a highlight for the government, education observer and researchers. By this phenomenon, emerge an emergency in the improvement of our education.

Many government programs promote Literacy activities. Various efforts were also made to develop students' literacy skills. Curriculum, school programs, until classroom learning are injected with literacy words. Students are geared toward reading. It starts with the habit of reading at the beginning of learning process until the reading corner becomes part of the literacy activities. These indicate that literacy has become the government's attention.

Literacy, especially 'scientific literacy' has been an international research trend since four decades ago (Gallagher \& Harsch, 1997). Scientific literacy was introduced by Hurd (1958) that explained as the goal of science education. Scientific literacy has a broader meaning than simply reading and writing (Harlen, 2001; Holbrook \& Rannikmae, 2009). Various understanding of scientific literacy is coming up.
Based on the definition of PISA (Development, 2006), scientific literacy is defined as "the capacity to use scientific knowledge, to identify questions and draw conclusions based on the facts in order to understand the universe. ". Based on this definition, scientific literacy has four domains, namely scientific knowledge, scientific process, scientific context and attitude towards science. On the other hand, Bybee (1997) suggests a comprehensive theoretical scale and was better suited for the assessment of student's scientific literacy (Shwartz, Ben-Zvi, \& Avi, 2006). This assessment classifies the ability of scientific Literacy in some taxonomy, which include scientific illiteracy, nominal scientific literacy, functional scientific literacy, conceptual scientific literacy and multidimensional scientific literacy.

Since the 2000s, research on literacy has expanded widely in Indonesia. The literacy research includes various literacy capabilities, such as economic literacy (Murniatiningsih, 2017; Sina, 2012), information literacy (Hasugian, 2008), mathematical literacy (Abdi, Ikhsan, \& Marwan, 2013) and scientific literacy (Islami, Permanasari, \& Nahadi, 2015; Ni'mah, 2016). This indicates that there is a new trend research in Indonesia education. Scientific 
literacy also being trend research as well as research issues in various countries and international journals (Cavas, 2015).

This study provides an overview of the scientific literacy research in Indonesia. This is important, as there will always be a need for more up-to-date research. The main purpose of this article is to analyze the research results based on the content and methodological approach. From this analysis, this is expected to get more information, description and research map from scientific literacy has been done in Indonesia. This will provide direction in conducting further research and policy.

\section{METHOD}

The research method was conducted using descriptive content analysis study. Grouping various research results based on various aspects in the study. The research instrument used is adapted from Paper Classification Form (PCF) developed by Kizilaslan, Sözbilir, \& Yasar
(2012). The Paper Classification Form is presented in Appendix 1.

The articles which had been analyzed consist of 138 articles published in 2009-2017 and published in various national journals either indexed by DOAJ, SCOPUS, ISSN journals, or by other journal indexing agencies. This study is limited to the analysis of research journals on the topic of scientific Literacy.

\section{RESULTS AND DISCUSSION \\ Research Trends of Scientific Literacy in Indonesia}

Results of the study are presented in this section in tables and charts. Based on Figure 1, research of scientific literacy is not a new research theme in Indonesia. This just grows by the time. Indonesian researchers' interest in scientific literacy is very poor until 2013. Studies show an increasing trend from 2014 onwards.

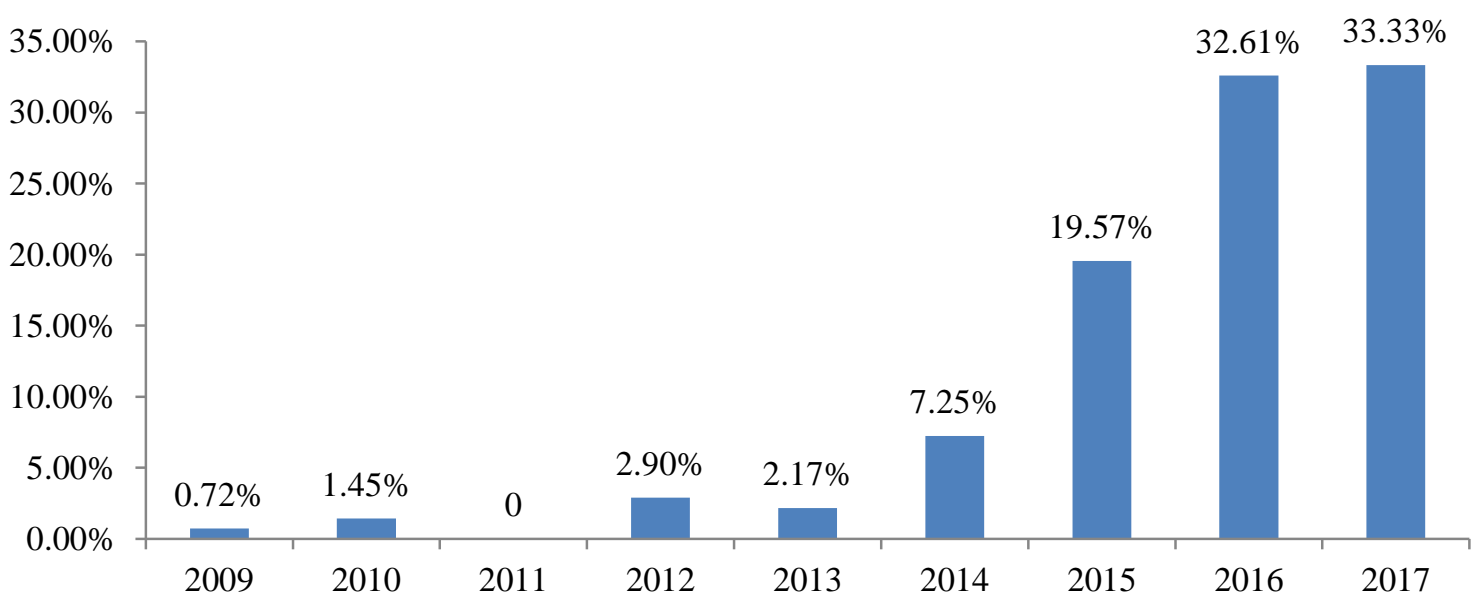

Figure 1. Number of research reports related to scientific literacy published over years.

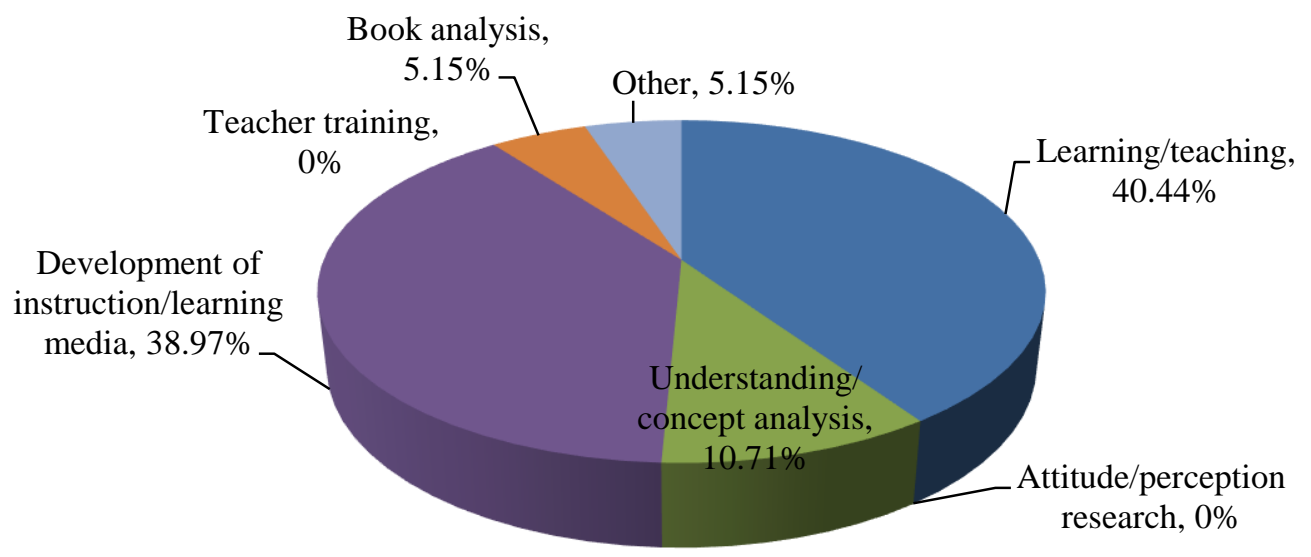

Figure 2. Research Topics in Scientific Literacy Research 


\section{Subject of the Research}

Based on Figure 2, Subject of the research is dominated by subject research of learning/ teaching $(40.44 \%)$ followed by the development of instruction/learning media (38.97\%) and Understanding/concept analysis (10.71\%). Scientific literacy research is dominated by the selection of learning models or learning innovations to develop students' literacy skills. This research is quite important, considering that this research is an applicative research that directly touches the ability of student's scientific literacy. The development or improvement of students' scientific literacy skills is also supported by the development of instruction/learning media. These research subjects can support the implementation of learning and innovation of learning process for the development of student's scientific literacy.

\section{Main Discipline that Paper Belonged}

Based on Figure 3, it has been found that science has a significant percentage (40\%), followed by Physics (18.38\%), Biology (17.65\%), Chemistry (16.18\%), Mathematics (3.63\%) and Environment/ other (3.68\%). The dominance of science in this aspect is related to the dominance of the research sample, where 15 years old students are.

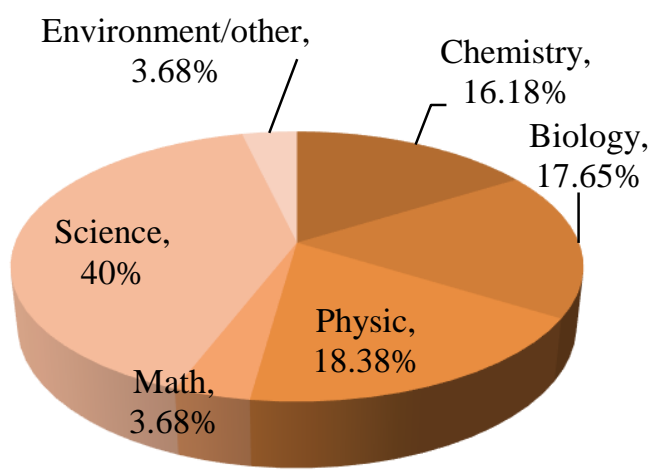

Figure 3. Field of Study in Scientific Literacy Research

\section{Scientific Literacy Definition}

Studies or reviews of scientific Literacy in literacy research are important. This is because the review provided provides an overview of the research and measurement thinking framework. Figure 4 displays that definition of scientific literacy according to PISA (52.94\%) is most often used by researcher. Other definitions of scientific literacy are explained according to Chiappeta et al. (2014) (11.03\%), ByBee (1997)
(5.88\%), Gormally et al. (2012) (2.94\%), and other definitions (3.68\%). Unfortunately, $23.53 \%$ of paper did not explain the definition of scientific literacy used as a research guide.

PISA is a program to assess education system simultaneously in various countries which is organized by the Organization for Economic Co-operation and Development (OECD). PISA was first implemented in 2000 and implemented every 3 years. Definition of scientific literacy is widely used as a reference in research that equal to $64.29 \%$ in this paper.

Shwartz (2006) explained the classification of student's scientific literacy ability on Bybee (1997) and BSCS (1993) into scientific illiteracy, nominal scientific literacy, functional scientific literacy, conceptual scientific literacy and multidimensional scientific literacy. Therefore, Bybee's classification of scientific literacy is more commonly used in student's scientific literacy study.

The other scientific literacy definition used in various scientific literacy research was proposed by Chiappeta, Filman, \& Sethna (1991). Scientific literacy-based books must have several categories, namely science as the body of Knowledge, science as the investigation tools of nature, science as a way of thinking, and interaction of science, environment, technology and society (Chiappeta et al., 1991). Its definition is preferred for research on the topic of book/ teaching materials analysis.

Gormally, Brickman, \& Mary (2012) developed Test of Scientific Literacy Skills (TOSLS) with National Research Council (NRC) $\&$ PISA definition of scientific literacy as framework. The instrument consists of 28 multiplechoice questions, which are contextualized around real-world problems. The instrument was developed into some categories of scientific literact skills: (I) Understanding methods of inquiry that lead to scientific knowledge, (1) Identify a valid scientific argument, (2) Evaluate the validity of sources, (3) Evaluate the use and misuse of scientific information, (4) Understand elements of research design and how they impact scientific findings/conclusions, (II) Organize, analyze, and interpret quantitative data and scientific information, (5) Create graphical representations of data, (6) Read and interpret graphical representations of data, (7) Solve problems using quantitative skills, including probability and statistics, (8) Understand and interpret basic statistics, and (9) Justify 
inferences, predictions, and conclusions based on quantitative data.

These nine skills in the instrument (TOSLS) are important to reveal the extent of students' literacy development. By this kind of development research, Gormally's work is suitable and often used as framework for testing, assessing students scientific literacy and the categories of instrument are used to develop instrument in different context. Fives, Huebner, \& Birnbaum (2014) defined scientific literacy as the ability to understand the process and engage meaningfully with the scientific information available in daily life. Fives et al. (2014) developed a scientific literacy assessment instrument called the Scientific Literacy Assessment (SLA). The instrument created to assess scientific process, students' motivation and belief in science. Assessment of process aspects developed which consisted of the role of science, thinking and working scientifically, science and society, literacy of science media, mathematics in science, and motivation and belief in science. This assessment could be an alternative to scientific literacy evaluation.

Assessment of Scientific Literacy Domain

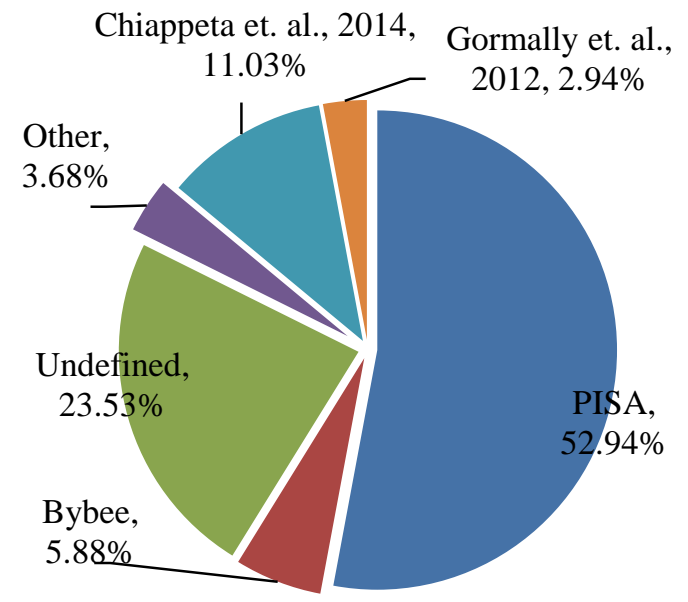

Figure 4. Scientific Literacy Definition Assessment of Scientific Literacy Domain

A deeper analysis of scientific Literacy studies can be seen from the domain or aspect that assessed in the paper. Based on Figure 5 the scientific Literacy domain consist of scientific content $(20.24 \%)$, scientific process $(20.63 \%)$, scientific context $(12.70 \%)$, attitude toward science $(12.30 \%)$, Scientific Literacy $(17.06 \%)$, other definitions $(12.30 \%)$, and other variables $(4.76 \%)$.

The Scientific Literacy that reaches $17.06 \%$ is a dependent variable of scientific literacy that is not translated or described into more specific domains. Scientific literacy definitions based on PISA dominate the scientific literacy research paper. This definition by PISA describes the scientific literacy into more specific domains; they are scientific content, scientific context, scientific processes, and attitudes toward science. Based on the findings, scientific content and scientific processes became most investigated domain, followed by a scientific context and an attitude toward science. This shows that concentration of researchers still focused on scientific content and scientific processes and still lacking for students' attitudes. Scientific context as "recognizing life situations involving science and technology", this means that students understand the context of everyday life that involves science and technology. In this case, scientific context is the selection of a lifeappropriate context with the students, covering the problems faced by students every day to solving global issues (Bybee, 2008; Development, 2006).

Other variables that also become dependent variables and are associated with scientific literacy in various studies are students' self-confidence (Islami et al., 2015), critical thinking skills (Rahayuni, 2016), environmental awareness (Perkasa \& Aznam, 2016; Sya'ban \& Wilujeng, 2016), student characters (Ajie, Ramalis, \& Liliawati, 2013), and misconceptions (Imaningtyas, Karyanto, Nurmiyati, \& Asriani, 2016).

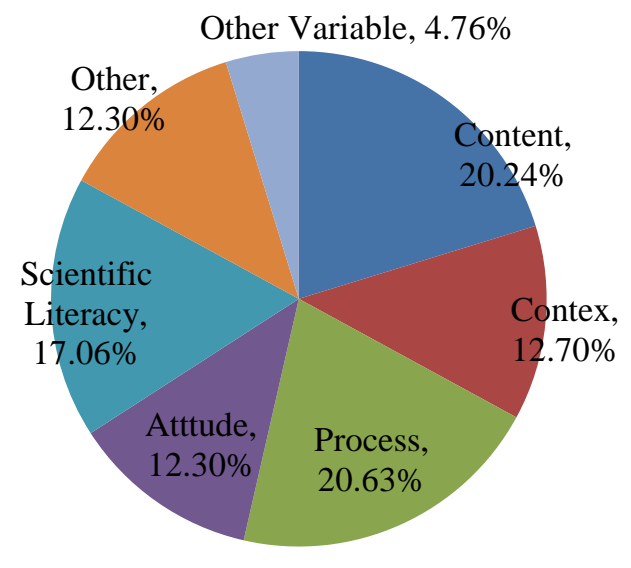

Figure 5. Scientific Literacy Domain

\section{Research Methods}

Research method in these scientific Literacy research is dominated by quantitative research (57.46\%), R \& D (35.07\%), Mix-Design $(3.73 \%)$ and qualitative $(3.73 \%)$. For in-depth analysis, the quantitative research is further 
elaborated into various types of research, and quasi-experimental research dominates scientific Literacy research which is followed by preexperimental research. This trend is also expressed by (Gul \& Sozbillir, 2016), that the trend of experimental research is dominated by quasi-experimental research and followed by preexperimentation.

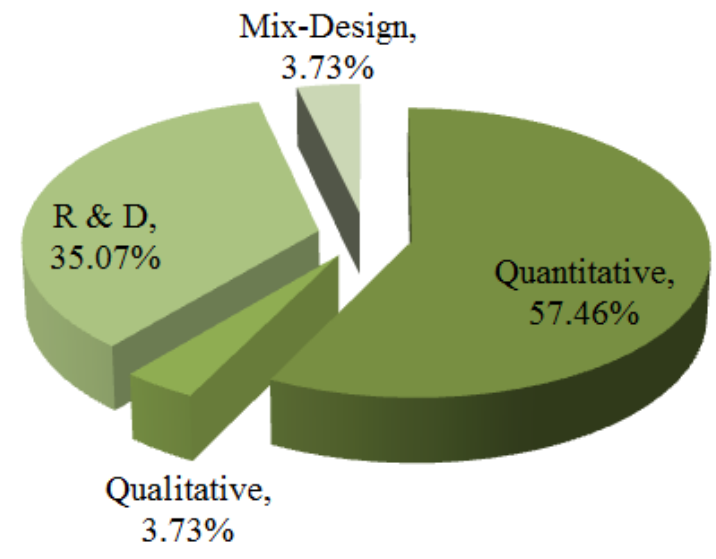

Figure 6. Research Methods in Scientific Literacy Research

There is no true-experimental research was found in this study, because in true-experimental research needs to randomize the sample/ participants into the group (Cresswel, 2012). On the other hand, quasi-experiment facilitates to not randomize the class members into different class/ group. Then we could use this nature group as our sample. This is also expressed by (Gul \& Sozbillir, 2016) that the absence of participant randomization is one factor that makes quasiexperimental research more preferable.

Table 1. Research Methods in Scientific Literacy Research

\begin{tabular}{lcc}
\hline Research Methods & $\mathrm{f}^{*}$ & $\%$ \\
\hline Quantitative & 77 & 57,46 \\
Quasi-experimen & 34 & \\
Pra-experimen & 18 & \\
Descriptive & 16 & \\
Corelational & 1 & \\
$\quad$ Survey & 8 & \\
Qualitative & 5 & 3,73 \\
R \& D & 47 & 35,07 \\
Mix-Design & 5 & 3,73 \\
\hline
\end{tabular}

Sample Research

Based on Figure 7, the sample in the scientific Literacy study was dominated by junior high school students with a percentage of $40.58 \%$. This dominance was followed by sample of high school students (31.88\%), undergraduate student $(13.04 \%)$, no sample (3.62\%), others $(4.35 \%)$ and teacher $(1.45 \%)$. Samples covered in other categories $(4.35 \%)$ include the study of textbooks, teaching materials, and curriculum.

The dominance of junior high school students was also reported by (Kizilaslan et al., 2012) in inquiry study from various Turkish national journals. A detailed analysis which is based on various types of the sample is shown in Table 1.

\section{Sample Size}

Figure 8 shows sample size in research of scientific Literacy from various papers. Unfortunately, $28.23 \%$ papers did not explain the sample size. Then, sample size within 51-100 (25.00\%) was the most frequently used in research paper. Moreover, sample size within 31$50(21.77 \%)$ and sample size within 11-30 $(12.90 \%)$ were following the dominance. The dominance of sample size was also reported by (Kizilaslan et al., 2012), which sample size within 31-100 dominate in national papers $(67.7 \%)$ and international papers $(88.9 \%)$. Only few paper with large sample size (2.42\%).

\section{Method Analysis}

The analytical methods used to elucidate the scientific literacy research results are presented in Table 2. The table indicates that the descriptive analysis is used frequently, especially the Normal gain-score analysis. The normal gainscore analysis method is considered to be quite effective because it can describe and classify the development of scientific literacy capabilities (Hake, 1998).

Other descriptive analysis methods widely used are the frequency table or percentage $\%$, and normal diagrams. This trend is also similar to the results of analysis (Kizilaslan et al., 2012), that descriptive analysis method is more widely used in research in various research journals followed by inferential statistics and qualitative analysis. This trend is also reported by (Gul \& Sozbillir, 2016) that descriptive method dominates the analysis methods used in various international journals in 2012-2014 and is also followed by inferential statistical analysis methods and qualitative analysis methods. 
Jurnal Inovasi Pendidikan IPA, 5 (1), 2019 - 28

Fatchiyatun Ni'mah

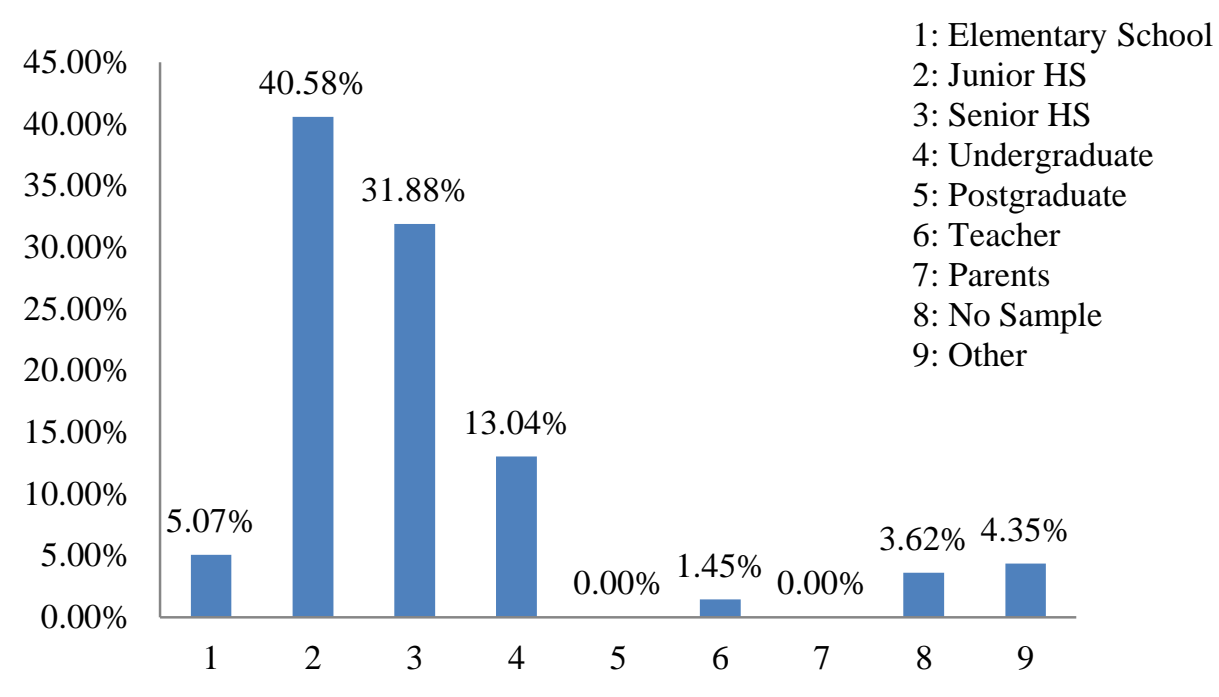

Figure 7. Samples in Scientific Literacy Research

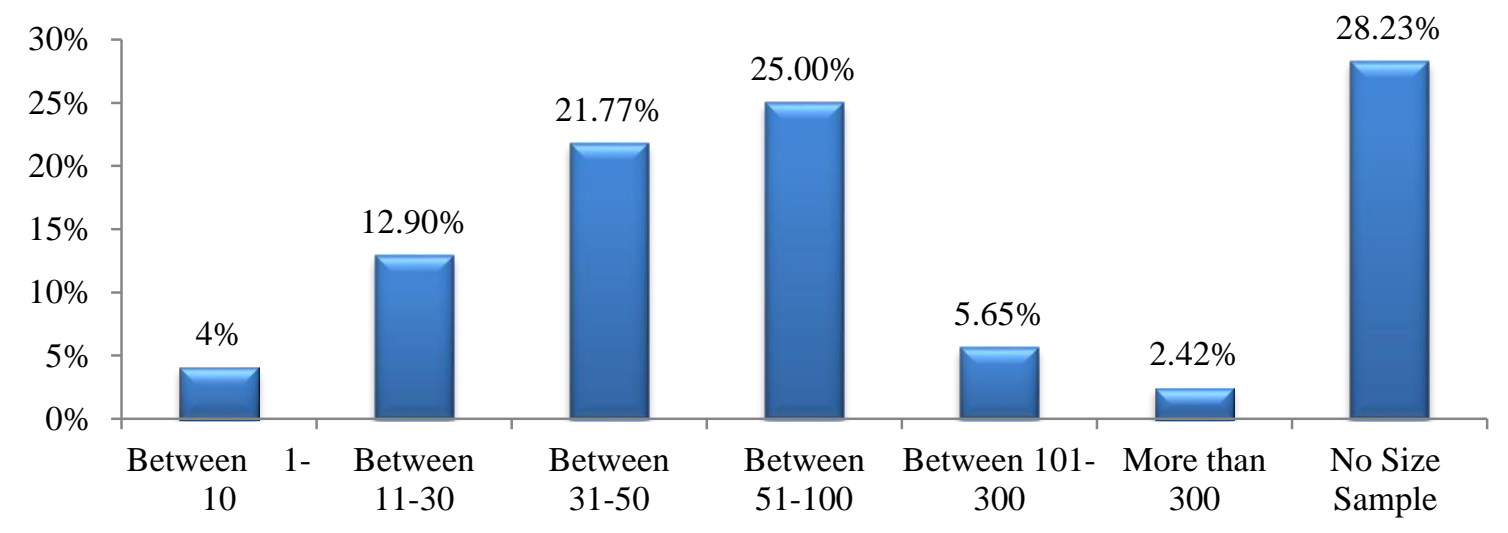

Figure 8. Sample Size in Scientific Literacy Research

Table 2. Analysis Methods in Scientific Literacy Research

\begin{tabular}{lcr}
\hline Analysis Methods & $\mathrm{f}^{*}$ & \multicolumn{1}{c}{$\%$} \\
\hline Descriptive Analysis & 175 & 78,48 \\
Frequency table (\%) & 67 & 30,04 \\
Normal Gain-score & 61 & 27,35 \\
Chart & 45 & 20,18 \\
Other & 2 & 0,90 \\
Statistik inferensial & 42 & 18,83 \\
t-test & 23 & 10,31 \\
Corelation & 2 & 0,90 \\
Anova/Anacova & 4 & 1,79 \\
Manova/Mancova & 4 & 1,79 \\
Regresi & 1 & 0,45 \\
Uji non-prametris & 8 & 3,59 \\
Qualitative & 6 & 2,69 \\
Content Analysis & 4 & 1,79 \\
Descriptive Analysis & 2 & 0,90 \\
\hline TOTAL & 223 & 100 \\
\hline
\end{tabular}

Instrument Type

Based on Table 3 the most commonly used instrument type is multiple choices (65.38\%) which are used to measure content, context, and process. This dominance was followed by a multiple choice/questionnaire to measure students' attitudes by a percentage of $17.95 \%$.

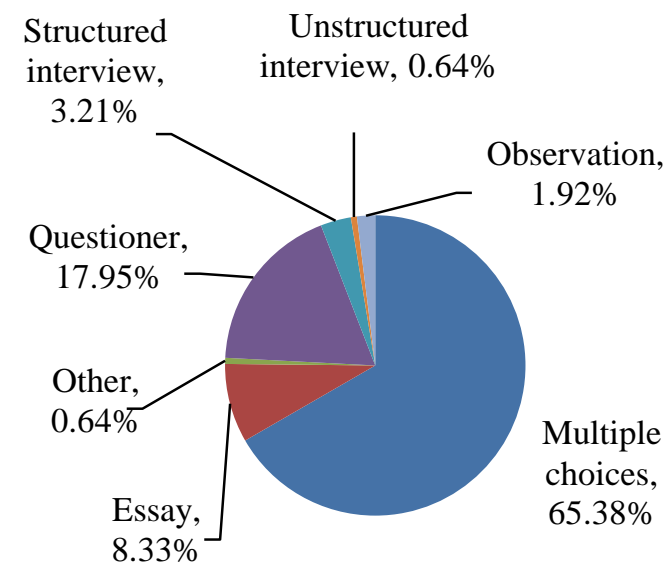

Figure 9. Comparison of Instrument Type in Scientific Literacy Research 
Table 3. Types of Instruments in Scientific Literacy Research

\begin{tabular}{|c|c|c|}
\hline Variable/Type of Instrument & $f^{*}$ & $\%$ \\
\hline - Conten, Contex, and process & 49 & 75,64 \\
\hline Multiple choice & 102 & 65,38 \\
\hline Essay & 13 & 8,33 \\
\hline Other & 1 & 0,64 \\
\hline - Attitude & 38 & 24,36 \\
\hline Questionaire/multiple choice & 28 & 17,95 \\
\hline Structured interview & 5 & 3,21 \\
\hline Unstructured interview & 1 & 0,64 \\
\hline Observation & 3 & 1,92 \\
\hline TOTAL & 156 & 100 \\
\hline
\end{tabular}

\section{CONCLUSION}

Based on the results of data analysis, the research of scientific Literacy in Indonesia is dominated by the application of learning that aims to develop students' literacy skills, especially the application of inquiry-based learning model. Science becomes the main discipline that dominates scientific literacy research, with junior high school students as frequently used sample. The majority of size samples within 31-50. Most scientific literacy definitions used is definition formulated by PISA with scientific content domains dominate the assessment. Major research designs use quasiexperimental design. The majority of research instruments used is multiple choices.

\section{REFERENCES}

Abdi, J., Ikhsan, M., \& Marwan. (2013). Meningkatkan kemampuan siswa sekolah menengah atas dalam menyelesaikan soal matematika setara pisa melalui pendekatan konstruktivisme. Jurnal Peluang, 1(2), 5162.

Ajie, W. T. S., Ramalis, T. R., \& Liliawati, W. (2013). Penerapan Metode science literacy circles (SLC) untuk meningkatkan literasi sains dan mengembangkan karakter siswa SMP. Jurnal Wahana Pendidikan Fisika, 1(1), 12-17.

Bybee, R. W. (1997). Achieving scientific literacy: From purposes to practices: ERIC.

Bybee, R. W. (2008). Scientific literacy, environmental issues, and PISA 2006: : The 2008 Paul F-Brandwein Lecture. Journal of Science Education and Technology, 17(6), 56-58.
Cavas, B. (2015). Research trends in science education international: A content analysis for the last five years (2011-2015). Science Education International, 25(4), 573-588.

Chiappeta, E., Filman, D., \& Sethna, G. (1991). A method to quantify major themes of scientific literacy in science textbooks. Journal of Research in Science Teaching, 28(8), 713-725.

Cresswel, J. (2012). Educational Research: planning, conducting and evaluating quantitative and qualitative research (4th $E d)$. Boston: Pearson.

Assessing Scientific, Reading and Mathematical Literacy A Framework for PISA 2006, (2006).

Fives, H., Huebner, W., \& Birnbaum, A. (2014). Developing a measure of scientific literacy for middle school students. Science Education, 98(4), 549-580.

Gallagher, J., \& Harsch, G. (1997). Scientific literacy: Science education and secondary school students. Paper presented at the Scientific literacy: An international symposium Kiel, Germany.

Gormally, C., Brickman, P., \& Mary, L. (2012). Developing a test of scientific literacy skills (TOSLS): measuring undergraduates' evaluation of scientific information and arguments. CBE-Life Sciences Education, 11, 364-377.

Gul, S., \& Sozbillir, M. (2016). International trends in biology education research from 1997 to 2014: A content analysis of papers in selected journals. Eurasia Journal of Mathematics, Science \& Technology Education, 12(6), 1631-1651.

Hake, R. (1998). Interactive-engagement versus traditional methods: A six-thousandstudent survey of mechanics test data for introductory physics courses. American Journal of Physics, 66(1), 74.

Harlen, W. (2001). The assessment of scientific literacy in the OECD/PISA project. Studies in Science Education, 36(1), 103.

Hasugian, J. (2008). Urgensi literasi informasi dalam kurikulum berbasis kompetensi di perguruan tinggi. Jurnal Studi Perpustakaan dan Informasi, 4(2), 34-44.

Holbrook, J., \& Rannikmae, M. (2009). The meaning of scientific literacy. 
International Journal of Environmental \& Science Education, 4(3), 275-288.

Hurd, P. D. (1958). Science literacy: Its meaning for American schools. Educational Leadership, 16(1), 13-16.

Imaningtyas, C. D., Karyanto, P., Nurmiyati, \& Asriani, L. (2016). Penerapan e-module berbasis problem based learning untuk meningkatkan literasi sains dan mengurangi miskonsepsi pada materi ekologi siswa kelas X MIA 6 SMAN 1 Karanganom Tahun Pelajaran 2014/2015. Bioedukasi, 9(1), 4-10.

Islami, R. A. Z. E., Permanasari, A., \& Nahadi. (2015). Hubungan literasi sains dan kepercayaan diri siswa pada konsep asam basa. Jurnal Penelitian dan Pembelajaran IPA, 1(1), 16-25.

Kizilaslan, A., Sözbilir, M., \& Yasar, M. (2012). Inquiry based teaching in Turkey: A content analysis of research reports. International Journal of Environmental \& Science Education, 7(4), 599-617.

Murniatiningsih, E. (2017). Pengaruh literasi ekonomi siswa, hasil belajar ekonomi, dan teman sebaya terhadap perilaku konsumsi siswa SMP Negeri di Surabaya Barat. Jurnal Ekonomi Pendidikan dan Kewirausahaan, 5(1), 127-156.

Ni'mah, F. (2016). Keefektifan model pembelajaran inkuiri semi terbuka (coupled inquiry) dan inkuiri terbimbing (guided inquiry) dalam mengembangkan literasi sains siswa SMA Kelas XI pada materi kimia. State University of Malang, Malang.

Perkasa, M., \& Aznam, N. (2016). Pengembangan SSP Kimia Berbasis Pendidikan Berkelanjutan untuk Meningkatkan Literasi Kimia dan Kesadaran terhadap Lingkungan. Jurnal Inovasi Pendidikan IPA, 2(1), 46-57.

Rahayuni, G. (2016). Hubungan keterampilan berpikir kritis dan literasi sains pada pembelajaran IPA terpadu dengan model PBM dan STM. Jurnal Penelitian dan Pembelajaran IPA, 2(2), 131-146.

Shwartz, Y., Ben-Zvi, R., \& Avi, H. (2006). The use of scientific literacy taxonomy for assessing the development of chemical literacy among high-school students. Chemistry Education Research and Practice, 7(4), 225.

Sina, P. (2012). Analisis literasi ekonomi. Economia: Kajian Ilmiah Ekonomi \& Bisnis, 8(2), 135-143.

Sya'ban, M. F., \& Wilujeng, I. (2016). Pengembangan SSP zat dan energi berbasis keunggulan lokal untuk meningkatkan literasi sains dan kepedulian lingkungan. Jurnal Inovasi Pendidikan $I P A,(1), 66-75$. 